\title{
JM
}

Volume 7 No. 1 (April 2019)

(C) The Author(s)

\section{HUBUNGAN MEDIA PEMBELAJARAN DAN MINAT TERHADAP MOTIVASI MAHASISWI TINGKAT IIIKEBIDANAN WIDYA KARSA JAYAKARTA}

\section{RELATIONSHIP OF LEARNING AND INTEREST MEDIA TOWARDS LEVEL II MOTIVATION OF STUDENTS WIDYA KARSA JAYAKARTA}

\author{
DESI AULIA UMAMI \\ PROGRAM STUDI KEBIDANAN (DIII) FAKULTAS ILMU KESEHATAN \\ UNIVERSITAS DEHASEN BENGKULU, ${ }^{, 1,2}$ \\ Email : desiumami@gmail.com
}

\begin{abstract}
ABSTRAK
Pendidikan merupakan suatu proses perubahan tingkah laku dan kemampuan seseorang menuju ke arah kemajuan dan peningkatan.Tujuan penelitian adalah mengetahui hubungan media pembelajaran dan minat belajar terhadap motivasi belajar pada mahasiswi tingkat III kebidanan widya karsa jayakarta tahun 2015. Penelitian ini menggunakan metode deskriptif analitik dengan menggunakan pendekatan cross sectional. Sampel dalam penelitian berjumlah 30 responden.Teknik pengambilan sampel menggunakan Total Sampling.Hasil penelitian berdasarkan uji univariat dan bivariat di peroleh gambaran responden yang mempunyai Motivasi belajar di Kebidanan Widya Karsa Jayakarta tingkat III tahun 2015 sebanyak 14 orang (46,7\%). Penggunaan media pembelajaran yang positif di Kebidanan Widya Karsa Jayakarta tingkat III tahun 2015 sebanyak 12 orang (40,0\%), sedangkan minat belajar di Kebidanan Widya Karsa Jayakarta tingkat III tahun 2015 sebanyak 11 orang $(37,7 \%)$. Hasil uji statistik bivariat media pembelajaran diperoleh nilai $\mathrm{p}=0,002$ sikap diperoleh nilai $\mathrm{p}=0,007$, Maka dapat disimpulkan ada hubungan antara media pembelajaran dengan motivasi belajar, ada hubungan antara minat belajar dengan motivasi belajar. Dari penelitian ini penulis memberikan saran untuk dosen pengajar lebih meningkatkan motivasi belajar pada mahasiswa agar tetap terus semangat belajar dan mendapatkan hasil belajar yang baik.
\end{abstract}

\section{Kata Kunci :Media Pembelajaran, Minat dan Motivasi}

\begin{abstract}
Education is a process change behavior and the ability someone toward the progress and increased. Research objectives is to know media relations of learning and interest learn to the motivation to study in a student of level III obstetrics widya karsa jayakarta 2015 .This research uses the method descriptive analytic by adopting cross sectional .Sample in research were 30 respondents .Technique the sample collection use total of sampling. The results of the study based on the univariat and bivariat in get picture respondents who had a the motivation to study in obstetrics widya karsa jayakartalevel iii 2015 the 14 (46,7 \% ).Media uses learning positive on obstetrics widya karsa jayakarta level iii 2015 as many as 12 people ( 40,0 \% ), while interest study in obstetrics widya karsa jayakarta level iii 2015 as many as 11 people ( of the $37.7 \%$ ).The results of statistical tests bivariat media learning obtained value $p=0,002$ attitude
\end{abstract}


obtained value $\mathrm{p}=0,007$, so can be concluded there was a correlation between the media learning with the motivation to study, there was a correlation between interest learn by the motivation to study.From the study writer give advice for a lecturer teaching more increased themotivation to study in students to keep eager to study and get study results good.

\section{Keywords :Instructional media, interest and motivation}

\section{PENDAHULUAN}

Pendidikan merupakan suatu proses perubahan tingkah laku dan kemampuan seseorang menuju ke arah kemajuan dan peningkatan. Pendidikan dapat mengubah pola pikir seseorang untuk selalu melakukan inovasi dan perbaikan dalam segala aspek kehidupan ke arah peningkatan kualitas diri. Pada pendidikan formal, penyelenggaraan pendidikan tidak lepas dari tujuan pendidikan yang akan di capai karena tercapai atau tidaknya tujuan pendidikan merupakan tolok ukur dari keberhasilan penyelenggaraan pendidikan. Tujuan pendidikan Nasional di sesuaikan dengan tuntutan pembangunan dan perkembangan bangsa Indonesia sehingga tujuan pendidikan bersifat dinamis.

Peningkatan mutu, kualitas dan biaya pendidikan di Indonesia ternyata mengalami masalah besar. Berdasarkan data tahunan menurut EFA (Education For All ) 2012 yang dikeluarkan oleh UNESCO (United Nation EducationScientific And Cultural Organization), kualitas pendidikan di Indonesia berada di peringkat ke-64 dari 120 negara di seluruh dunia. Pada tahun 2011 EDI (Education Development Index) Indonesia berada pada peringkat ke-69 dari 127 negara. Indonesia memiliki EDI 0,938. Dari empat tujuan pencapaian EFA (Education For All) 2015 yang dikaji UNESCO(United Nation Education Scientific And Cultural Organizatio) tiap tahun, Indonesia mampu meningkatkan akses pendidikan dasar yang tinggi dengan nilai 0,991 .

Pada tingkat Asia, Indonesia masih tertinggal dari Brunei Darusalam dalam penggunaan media pembelajaran yaitu 43,5\% sedangkan Brunei Darusalam yaitu
45,8\% dan masuk kelompok pencapaian tinggi bersama Jepang, yang mencapai posisi nomer 1 di Asia. Adapun Malaysia berada diperingkat ke -65 atau masih dalam kelompok medium sama seperti halnya Indonesia. Meskipun demikian posisi Indonesia saat ini jauh lebih baik dari Filipina ke- 85, Kamboja ke -102, India ke - 107, dan Laos ke -109.

Terdapat faktor yang menjadikan rendahnya kualitas pendidikan di Indonesia. beberapa faktor tersebut adalah : (1) rendahnya kualitas sarana prasarana, penggunaan media belajar yang rendah, buku perpustakaan tidak lengkap (2) rendahnya kualitas guru, karena kebanyakan guru belum memiliki profesionalisme yang memadai untuk menjalankan tugasnya sebagaimana disebut dalam pasal 39 UU No.20/2003 yaitu merencanakan pembelajaran, melaksanakan pembelajaran, menilai hasil pembelajaran, melakukan bimbingan, melakukan pelatihan, melakukan penelitian dan melakukan pengabdian masyarakat, (3) Rendahnya kesejahteraan guru, mempunyai peran dalam rendahnya kualitas pendidikan di Indonesia. ${ }^{4}$

Dalam hal prestasi, pada tanggal 15 September 2004 UNDP (United Nations Development Programme) telah mengumumkan hasil studi tentang kualitas manusia secara serentak di seluruh dunia melalui laporannya yang berjudul Human Development Report 2004. Di dalam laporan tahunan ini Indonesia hanya menduduki posisi ke 111 dari 177 negara, rendahnya relevansi pendidikan dengan kebutuhan, hal ini dapat dilihat dari banyaknya lulusan yang menganggur. Menurut data BAPPENAS (Badan Perencanaan Pembangunan Nasional ) tahun 1996 yang dikumpulkan sejak tahun 1990 menunjukan angka pengangguran yang dihadapi oleh lulusan SMU sebesar.

Sejalan dengan perkembangan teknologi, 
maka media pembelajaran pun mengalami perkembangan melalui pemanfaatan teknologi itu sendiri. Berdasarkan teknologi tersebut, beberapa jenis diklasifikasikan atas empat kelompok, yaitu : a) Media hasil teknologi cetak, b) Media hasil teknologi audio-visual, c) Media hasil teknologi yang berdasarkan computer, d) Media hasil gabungan teknologi cetak dan komputer.

Penggunaan media pembelajaran sebagai sumber belajar merupakan alat bantu yang berguna dalam kegiatan belajar mengajar. Alat bantu dapat mewakili sesuatu yang tidak dapat disampaikan dosen melalui kata-kata. Keefektifan daya serap anak didik terhadap bahan pelajaran yang sulit dan rumit dapat terjadi dengan bantuan alat bantu. Selain itu kesulitan anak didik memahami konsep dan prinsip tertentu dapat diatasi dengan bantuan alat bantu. Bahkan alat bantu diakui dapat melahirkan umpan balik yang baik dari anak didik, dengan memanfaatkan taktik alat bantu yang akseptabel, sehingga dosen dapat menimbulkan minat belajar pada anak didik.

Media pembelajaran terdapat fungsi yang dapat memotivasi minat dan tindakan yang artinya dapat melahirkan minat dan merangsang para mahasiswi atau pendengar untuk bertindak. Fungsi kedua yaitu menyajikan informasi yang berfungsi sebagai pengantar ringkasan laporan, atau pengetahuan latar belakang.

Minat ini memiliki hubungan yang besar terhadap belajar sebab dengan minat seseorang akan melakukan sesuatu, sebaliknya tanpa minat tidak mungkin melakukan sesuatu. Keterlibatan mahasiswi dalam belajar erat kaiatannya dengan sifatsifat mahasiswi, baik yang bersifat kognitif seperti kecerdasan dan bakat maupun yang bersifat afektif, seperti motivasi, rasa percaya diri, dan minatnya. Minat mahasiswi merupakan faktor utama yang menentukan derajat keefektifan belajar mahasiswi. Jadi, unsur afektif merupakan faktor yang menentukan keterlibatan mahasiswi secara aktif dalam proses pembelajaran.

Menurut penelitian yang dilakukan oleh
Tria yang berjudul "Hubungan Media Pembelajaran Jobsheet dan Motivasi Belajar Terhadap Hasil Belajar Pada Mata Pelajaran Akuntansi Kelas XI IPS di SMA Pasundan 2 Bandung".media pembelajaran jobsheet pada mata pelajaran akuntansi di kelas XI IPS SMA Pasundan 2 Bandung tergolong tinggi, motivasi belajar siswa tergolong sedang, dan hasil belajar siswa tergolong sedang. Dan hasil penelitian juga menunjukkan bahwa media pembelajaran jobsheet dan motivasi belajar berhubungan positif terhadap hasil belajar siswa.kegiatan belajar mengajar di dapatkan dari 32 mahasiswi di kelas ada 6 (18,75\%) mahasiswi yang mengobrol dengan temannya, $6(18,76 \%)$ mahasiswi melakukan aktivitas yang tidak berhubungan dengan pelajaran, hanya ada $10(31,25 \%)$ mahasiswi yang aktif berdiskusi saat diminta mengerjakan soal. Hasil kesimpulan maka dari kondisi kelas tersebut sekitar $68,75 \%$ mahasiswi tidak aktif. Namun belum diketahui hubungan media pembelajaran dan minat belajar terhadap motivasi belajar pada mahasiswi tingkat III kebidanan widya karya jayakarta tahun 2015. Variabel independen dalam kerangka konsep penelitian ini ada 2 variabel yaitu media pembelajaran dan minat.Variabel dependen adalah motivasi belajar. Dari data diatas, penulis tertarik untuk melakukan penelitian yang berjudul : "Hubungan Media pembelajaran dan Minat belajar terhadap Motivasi belajar maasiswi tingkat III Kebidanan Widya Karsa jayakarta tahun 2015.

\section{METODE PENELITIAN}

Penelitian ini termasuk dalam penelitian kuantitatif dengan penelitian deskriptif analitik dengan menggunakan desain cross sectional yaitu suatu penelitian pada beberapa populasi yang diamati dalam waktu yang bersamaan pengukuran terhadap variabel independen (Media Pembelajaran dan Minat belajar) dan variabel dependen (Motivasi belajar) dimana pengukuran terhadap variabel dependent dan independent dapat dilakukan dalam waktu bersamaan sehingga cukup efektif dan efisien.

Penelitian ini dilakukan di Akademi 
Kebidanan Widya Karsa Jayakarta Penelitian ini dilakukan pada bulan Juni tahun 2015. Populasi adalah keseluruhan objek atau subjek yang berada pada suatu wilayah dan memenuhi syarat-syarat tertentu berkaitan dengan masalah penelitian, atau keseluruhan unit, individu dalam ruang lingkup yang akan diteliti. Populasi dalam penelitian ini adalah mahasiswi Tingkat III Akademi Kebidanan Widya Karsa Jayakarta Tahun 2015 yang berjumlah 30 mahasiswi.

Sampel adalah bagian dari populasi yang dianggap dapat mewakili dari populasi tersebut. Penentuan jumlah sample dapat dilakukan dengan cara perhitungan statistik yaitu dengan menggunakan Rumus Solvin. ${ }^{10}$ Rumus Solvin digunakan untuk menentukan ukuran sample dari populasi yang telah diketahui jumlahnya yaitu sebanyak 30 Mahasiswi. Besarnya sample dalam penelitian ini dihitung menggunakan rumus Solvin maka didapatkan hasil yang ada berjumlah $30 \quad$ Mahasiswi. Teknik pengambilan sampel pada penelitian ini adalah Total Sampling menjelaskan teknik Total Sampling bertujuan untuk mengambil sample dengan tujuan tertentu. Sehingga sample yang diambilnya yang dijumpai di tempat penelitian dengan jumlah sample yang telah ditentukan.

\section{HASIL PENELITIAN}

Pada analisis univariat data yang telah dipeoleh dari hasil pengumpulan data disajikan dalam bentuk tabel distribusi frekuensi dan teks.Dimana variabel independennya yaitu media pembelajaran dan minat belajar, variabel dependen yaitu motivasi belajar.

Data Univariat dalam penelitian ini terdiri dari motivasi belajar, media pembelajaran dan minat belajar. Pada penelitian ini, terdapat penelitian yang akan di kelompokan meliputi variabel dependen motivasi belajar.

Pada penelitian ini menggunakan analisia univariat dan bivariat. Analisa univariat adalah analisis untuk mengetahui gambaran dari tiap variabel independen (media pembelajaran, dan minat belajar) dan variabel dependen (motivasi belajar) data yang telah dipeoleh dari hasil pengumpulan data disajikan dalam bentuk tabel distribusi frekuensi dan teks. Dimana variabel independen dan dependen.

Dimana variabel independennya yaitu media pembelajaran dan minat belajar variabel dependen yaitu motivasi belajar. Analisa ini juga di gunakan menyederhanakan atau meringkas kumpulan data hasil pengukuran sehingga kumpulan data tersebut menjadi informasi yang berguna.Data Univariat dalam penelitian ini terdiri dari media pembelajaran dan minat belajar variabel dependen yaitu motivasi belajar.

Analisis bivariat dilakukan untuk mengetahui hubungan antara 2 variabel yaitu variabel bebas (media pembelajaran dan minat belajar) dengan variabel terikat (motivasi belajar) dengan menggunakan uji chi square pada $\alpha=5 \%$. Bila nilai $p>\alpha(5 \%)$ maka keputusannya Ha ditolak dan sebaliknya nilai $p<\alpha(5 \%)$ maka keputusanya Ho ditolak yaitu ada hubungan media pembelajaran dan minat belajar terhadap motivasi belajar pada mahasiswi Akademi Kebidanan Widya Karsa Jayakarta tahun 2015.

Pada angka tidak motivasi belajar berdasarkan distribusi frekuensi menunjukan bahwa rendah media pembelajaran memiliki nilai lebih besar sehingga distribusi frekuensi media pembelajaran rendah lebih besar dari pada media pembelajaran tinggi. Dan distibusi frekuensi menunjukan bahwa koping yang buruk mahasiswi baru memiliki nilai lebih besar sehingga distribusi frekuensi koping mahasiswa baru yang buruk lebih besar daripada koping yang baik mahasiswi baru.

Penyajian data dalam penelitian ini meliputi media pembelajaran dan minat belajar terhadap motivasi belajar pada mahasiswi Akademi Kebidanan Widya Karsa Jayakarta tahun 2015. Pada penelitian ini, terdapat penelitian yang akan di kelompokan menjadi 3. Penyajian data dalam penelitian ini meliputi media pembelajaran dan minat belajar terhadap motivasi belajar. Pada penelitian ini, 
terdapat penelitian yang akan di kelompokan meliputi variabel dependen motivasi belajar. Berdasarkan hasil olah data menggunakan komputerisasi didapatkan gambaran motivasi belajar, Media Pembelajaran dan Minat Belajar pada tabel berikut:

\section{Distribusi $\quad$ Frekuensi $\quad$ Media Pembelajaran, Dan Minat Belajar Terhadap Motivasi Belajar Tahun 2015.}

\begin{tabular}{ccc}
\hline Variabel & Frekuensi (f) & $\begin{array}{c}\text { Presentase } \\
(\%)\end{array}$ \\
\hline $\begin{array}{c}\text { Motivasi Belajar } \\
\text { Rendah }\end{array}$ & 16 & 53,3 \\
\hline Tinggi & 14 & 46,7 \\
\hline $\begin{array}{c}\text { Mediapembelajaran } \\
\text { Tidak baik }\end{array}$ & 18 & 60,0 \\
\hline Baik & 12 & 40,0 \\
\hline $\begin{array}{c}\text { Minat Belajar } \\
\text { Rendah }\end{array}$ & 19 & 63,3 \\
\hline Tidak & 11 & 36,7 \\
\hline
\end{tabular}

Sumber : Hasil Olahan Data Komputerisasi 2015

Penyajian data dalam penelitian ini meliputi media pembelajaran dan minat belajar terhadap motivasi belajar. Pada penelitian ini, terdapat penelitian yang akan di kelompokan meliputi variabel dependen motivasi belajar. Dibawah ini merupakan penjelasan yang mengenai pengumpulan data dari hasil analisis univariat yang memiliki variabel independen dan dependen.Dimana variabel independen di tabel yaitu media pembelajaran dan minat belajar sedangkan variabel dependen dari penelitian ini yaitu motivasi belajar.

Dari tabel di atas denga distribusi frekuensi data disajikan dalam bentuk tabel dan teks. Dari tabel 1 menunjukkan mahasiswa yang memiliki motivasi belajar rendah sebanyak 16 orang $(53,3 \%)$ sedangkan mahasiswa yamg memiliki motivasi belajar tinggi sebanyak 14 orang $(46,7 \%)$.

Distribusi frekuensi media pembelajaran di Akademi Kebidanan Widya Karsa Jayakarta tahun 2015. Diperoleh menggunakan media pembelajaran tidak baik sebanyak 18 orang $(60,0 \%)$ sedangkan yang menggunakan media pembelajaran baik 12 orang $(40,0 \%)$.

Distribusi frekuensi minat belajar di Akademi Kebidanan Widya Karsa Jayakarta tahun 2015. Diperoleh mahasiswa yang memiliki minat belajar yang rendah sebanyak 19 oarang $(63,3 \%)$ sedangkan yang memiliki minat belajar yang rendah sebanyak 11 orang $(36,7 \%)$.

\section{Hubungan Media Pembelajaran, DanMinat BelajarTerhadap Motivasi Belajar Tahun 2015.}

\begin{tabular}{|c|c|c|c|c|c|c|c|}
\hline \multirow[t]{3}{*}{ Variabel } & \multicolumn{4}{|c|}{ Motivasi } & \multirow{2}{*}{\multicolumn{2}{|c|}{ Total }} & \multirow{2}{*}{$\begin{array}{r}P \text { OR } \\
\text { Valu }(9 \\
\text { e } 5 \% \\
\text { CI) }\end{array}$} \\
\hline & \multicolumn{2}{|c|}{ Rendah } & \multicolumn{2}{|c|}{ Tinggi } & & & \\
\hline & $\mathrm{N}$ & $\%$ & $\mathrm{~N}$ & $\%$ & $\mathrm{~N}$ & $\%$ & \\
\hline $\begin{array}{l}\text { Media } \\
\text { Pembelajaran } \\
\text { Tidak baik }\end{array}$ & 14 & 77,8 & 4 & 22,2 & 18 & 100 & $\begin{array}{ll}0,00 & 17 . \\
2 & 50\end{array}$ \\
\hline Ya & 2 & 16,7 & $\begin{array}{l}1 \\
0\end{array}$ & 83,3 & 12 & 100 & $\begin{array}{c}2.6 \\
67- \\
114 \\
.84 \\
6 \\
\end{array}$ \\
\hline $\begin{array}{l}\text { Minat Belajar } \\
\text { Rendah }\end{array}$ & 14 & 73,7 & 5 & 26,3 & 19 & 100 & $\begin{array}{lr}0.00 & 12 . \\
7 & 60\end{array}$ \\
\hline Tinggi & 2 & 18,2 & 9 & 81,8 & 11 & 100 & $\begin{array}{c}1.9 \\
99- \\
79 . \\
43 \\
6\end{array}$ \\
\hline
\end{tabular}

sumber : Hasil Olahan Data Komputerisasi 2015

Berdasarkan tabel 2 hasil analisis hubungan antara media pembelajaran dengan motivasi belajar diperoleh bahwa dari 18 mahasiswa yang media pembelajarannya tidak baik terdapat 14 responden $(77,8 \%)$ yang motivasinya rendah dan 4 responden $(22,2 \%)$ yang motivasinya tinggi. Sedangkan dari 12 mahasiswa yang media pembelajarannya baik terdapat 2 responden ( $16,7 \%)$ memiliki motivasi rendah dan 10 responden $(83,3 \%)$ yang motivasi tinggi. Dari hasil uji statistik 
didapat nilai $\mathrm{P}=0,002$ berarti $\mathrm{P}<0,05$, sehingga dapat disimpulkan ada hubungan antara media pembelajaran dengan motivasi belajar. Dengan nilai OR 17.500 berarti responden yang menggunakan media pembelajaran tidak baik berpeluang $17 \mathrm{kali}$ untuk memiliki motivasi belajar yang rendah di bandingkan yang tinggi.

Hasil analisis hubungan antara minat belajar terhadap motivasi belajar diperoleh bahwa bahwa dari 19 mahasiswi yang minatnya rendah terdapat 14 responden $(73,7 \%)$ yang motivasinya rendah dan 5 responden $(26,3 \%)$ yang motivasinya tinggi. Sedangkan dari 11 mahasiswi yang minatnya tinggi terdapat 2 responden $(18,2 \%)$ yang motivasinya rendah dan 9 responden $(81,8 \%)$ yang motivasinya tinggi. Dari hasil uji statistik didapat nilai $\mathrm{P}=0,007$ berarti $\mathrm{P}$ $<0,05$, sehingga dapat disimpulkan ada hubungan antara minat belajar dengan motivasi belajar. Dengan nilai OR 12.600 responden yang minat belajar yang rendah berpeluang 12 kali untuk memiliki motivasi yang rendah di bandingkan yang tinggi.

\section{PEMBAHASAN}

Rancangan penelitian ini menggunakan pendekatan cross sectional yaitu semua variabel dikumpulkan dalam waktu yang bersamaan sehingga menimbulkan kelemahan yaitu tidak terpenuhinya urutan waktu dimana penyebab harus mendahului akibat. Mengingat keterbatasan waktu, dana, dan kemampuan peneliti maka dalam penelitian ini hanya mengetahui distribusi frekuensi hubungan antara hubungan antara media pembelajaran dan minat terhadap motivasi belajar pada mahasiswi akademi kebidanan Widya Karsa Jayakarta tahun 2015.

Penelitian ini menggunakan data primer yang di peroleh dari penyebaran kuesioner pada mahasiswi tingkat III akademi kebidanan Widya Karsa Jayakarta tahun 2015.Penelitian ini tidak terlepas dari keterbatasan, di antaranya pengetahuan yang dimiliki oleh penulis, waktu penelitian yang di lakukan peneliti sangat singkat.

Alat ukur yang di gunakan adalah kuesioner yang bersifat subjektif karena kebenaran data dari hasil kuesioner sangat bergantung pada kejujuran responden dalam menjawab dan waktu yang terbatas di dalam penyebaran kuesioner di karenakan jadwal mahasiwi tingkat III akademi kebidanan widya karsa jayakarta ingin melaksanakan lokmil.

\section{MOTIVASI BELAJAR}

Motivasi belajar dapat di ukur dengan menggunakan alat ukur kuesioner yaitu menjawab pertanyaan sebanyak 15 pertanyaan. Hasil keseluruhan kuesioner di akumulasikan dan di bagikan dengan jumlah responden sehingga di dapatkan nilai rata- rata motivasi belajar rendah sebanyak 16 orang $(53,3 \%)$ sedangkan mahasiswa yamg memiliki motivasi belajar tinggi sebanyak 14 orang $(46,7 \%)$.

Hasil penelitian senada dengan penelitian Marfiani yang telah di lakukan bahwa pengaruh motivasi terhadap belajar adalah dorongan yang mendapatkan usaha untuk melakukan atau memuaskan suatu kebutuhan atau tujuan disebut motivasi. Untuk mengembangkan sikap-sikap positif yang akan mengarahkan mahasiswi pada pencapaian tujuan belajar, maka motivasi harus ditingkatkan baik motivasi eksternal maupun motivasi internal. Motivasi merupakan dorongan,upaya dan keinginan yang ada pada diri manusia yang akan mengarahkan perilaku untuk melakukan tugas atau pekerjaan dengan baik.

Hal ini sesuai dengan teori yang dikemukakan oleh Hamalik mengemukakan bahwa pemakaian media pengajaran dalam proses belajar mengajar dapat membangkitkan keinginan dan minat yang baru, membangkitkan motivasi dan rangsangan kegiatan belajar, dan bahkan membawa pengaruh-pengaruh psikologis terhadap siswa.

Hal ini sesuai dengan penelitian M.Nur Awaludin (2010) yang berjudul "Penggunaan Media Pembelajaran untuk Meningkatkan Motivasi Siswa dalam Pembelajaran Fiqih di Madrasah Tsanawiyah Negeri Batu".Dalam 
penelitiannya tertulis sama dengan teori yang dikemukakan oleh Hamalik (2008) yaitu pemakaian media pengajaran dalam proses belajar mengajar dapat membangkitan keingintahuan dan minat baru bagi siswa, serta membangkitkan motivasi dan rangsangan kegiatan belajar mengajar dan bahkan membawa pengaruh psikologis terhadap siswa.

Motivasi berasal dari kata motif yang dapat diartikan sebagai kekuatan yang terdapat dalam diri individu, yang menyebabkan individu tersebut bertindak atau berbuat.Uno menyimpulkan motivasi merupakan dorongan yang terdapat dalam diri seseorang untuk berusaha mengadakan perubahan tingkah laku yang lebih baik dalam memenuhi kebutuhannya.mengemukakan bahwa motivasi dapat dipahami sebagai suatu variabel penyelang yang digunakan untuk menimbulkan faktor-faktor tertentu di dalam organisme, yang membangkitkan, mengelola, mempertahankan, dan menyalurkan tingkah laku menuju suatu sasaran.

Motivasi telah banyak dikemukakan oleh para ahli.Pengertian motivasi dapat dilihat dari pengertian dasarnya yaitu motif. Menurut Ngalim Purwanto, segala sesuatu yang mendorong seseorang untuk bertindak melakukan sesuatu disebut motif,sedangkan menurut Sardiman, motif dapat dikatakan sebagai daya penggerak dari dalam dan di dalam subjek untuk melakukan aktivitasaktivitas tertentu demi mencapai suatu tujuan. Berawal dari kata motif itu, maka motivasi dapat diartikan sebagai daya penggerak yang telah menjadi aktif.Motif yang menjadi aktif.

Motivasi dapat dikatakan sebagai keseluruhan daya penggerak di dalam diri mahasiswi yang menimbulkan kegiatan belajar, yang menjamin kelangsungan dari kegiatan belajar dan yang memberikan arah pada kegiatan belajar, sehingga tujuan yang dikehendaki oleh subjek belajar dapat tercapai.

Dari semua pengertian mengenai motivasi belajar di atas maka dapat di sintesakan bahwa yang dimaksud dengan motivasi belajar adalah sesuatu yang mampu memberikan dorongan kepada mahasiswi untuk belajar dan melangsungkan pelajaran dengan memberikan arah atau tujuan yang telah ditentukan. Menurut asumsi peneliti motivasi belajar adalah motivasi merupakan dorongan,upaya dan keinginan yang ada pada diri manusia yang akan mengarahkan perilaku untuk melakukan tugas atau pekerjaan dengan baik.

\section{MEDIA PEMBELAJARAN}

Media pembelajaran dapat di ukur dengan menggunakan alat ukur kuesioner yaitu menjawab pertanyaan sebanyak 15 pertanyaan. Hasil keseluruhan kuesioner di akumulasikan dan di bagikan dengan jumlah responden sehingga di dapatkan nilai rata- rata mahasiswi menggunakan media pembelajaran tidak baik sebanyak 18 orang $(60,0 \%)$ sedangkan yang menggunakan media pembelajaran baik 12 orang $(40,0 \%)$.

Pengertian mengenai media telah banyak dikemukakan oleh para ahli. Kata media berasal dari bahasa latinmedius yang secara harfiahberarti tengah, perantara atau pengantar. Dalam bahasa Arab mediaadalah perantara atau pengantar pesan dari pengirim kepadapenerimapesan. Menurut Gerlach dan Ely yangdikutip oleh Azhar Arsyad, media apabila dipahami secara garisbesar adalah manusia, materi dan kejadian yang membangun kondisi yang membuat mahasiswi mampu memperoleh pengetahuan, keterampilan atau sikap.

Sadiman menyatakan bahwa media adalah segala sesuatu yang dapat digunakan untuk menyalurkan pesan dari pengirim ke penerima sehingga dapat merangsang pikiran, perasaan, perhatian dan minat serta perhatian mahasiswi sedemikian rupa sehingga proses belajar terjadi.

Ronquillo mengemukakan bahwa media pengajaran adalah bahan, alat, maupun metode/teknik yang digunakan dalam kegiatan belajar mengajar dengan maksud agar proses 
interaksi komunikasi edukatif antara guru dan anak didik dapat berlangsungsecara efektif dan efesien sesuai dengan tujuan pengajaran yang telah dicita-citakan.

Dari semua pengertian mengenai media pembelajaran di atas maka dapat di sintesakan bahwa yang dimaksud dengan media pembelajaran sebagai alat bantu mengajar untuk menyampaikan materi agar pesan lebih mudah diterima dan menjadikan mahasiswi lebih termotivasi dan aktif.

Menurut asumsi penelitian media pembelajaran bahwa semakin media pembelajaran memadai, semakin tinggi juga motivasi belajar siswa untuk belajar.Sebaliknya jika media pembelajaran tidak memadai, maka motivasi belajar siswa rendah.

\section{MINAT BELAJAR}

Minat belajar dapat di ukur dengan menggunakan alat ukur kuesioner yaitu menjawab pertanyaan sebanyak 15 pertanyaan. Hasil keseluruhan kuesioner di akumulasikan dan di bagikan dengan jumlah responden sehingga di dapatkan nilai ratarata ada sebanyak 19 orang (63,3\%) memiliki minat belajar rendah dan 11 orang (36,7\%) memiliki minat belajar tinggi.

Minat adalah kecenderungan yang tetap untuk memperhatikan dan mengenang beberapa kegiatan.Kegiatan yang diminati seseorang, diperhatikan terus menerus yang disertai dengan rasa senang. Selanjutnya Slameto berpendapat bahwa minat adalah suatu rasa lebih suka dan rasa keterikatan pada suatu hal atau aktivitas, tanpa ada yang menyuruh. Minat pada dasarnya adalah penerimaan akan suatu hubungan antara diri sendiri dengan sesuatu di luar diri. Suatu minat dapat diekspresikan melalui suatu pernyataan yang menunjukkan bahwa mahasiswi lebih menyukai suatu hal daripada hal lainnya, dapat pula dilihat melalui partisipasi dalam suatu aktivitas untuk lebih memperhatikan dan mengingat secara terus-menerus yang diikuti rasa senang.
Hasil penelitian ini senada dengan penelitian Sardi (2013) Berdasarkan hasil penelitian minat belajar berpengaruh secara signifikan terhadap hasil belajar siswa kelas XI IPS MAN se-kota Pontianak.Dibuktikan dengan analisis regresi linear sederhana dimana nilai $\mathrm{t}$ hitung sebesar $-2,859>$ nilai $\mathrm{t}$ tabel sebesar -1,975. Hasil penelitian ini sejalan dengan pendapat Abied (2009) yang menyatakan bahwa jika minat belajar siswa dapat dibangkitkan, kemudian seluruh perhatiannya dapat dipusatkan kepada bidang studi yang dipelajarinya, keadaan kelas dapat menjadi tenang, dengan demikian proses belajar dapat berlangsung dengan baik dan siswa pun dapat mencapai tujuan belajar sebagaimana yang diharapkan.

Sedangkan Penelitian Agus Widiyatmo (2010) menyimpulkan ada hubungan antara minat dan motivasi belajar dengan prestasi belajar, besarnya hubungan kedua variabel bebas (minat belajar dan motivasi belajar) sebesar $14,2 \%$, dapat dijabarkan pengaruh masing-masing variabel bebas yaitu sumbangan efektif (SE\%) variabel minat belajar $=5 \%$, sedangkan sumbangan efektif $(\mathrm{SE} \%)$ variabel motivasi belajar $=3 \%$. Sehingga dapat dinyatakan bahwa masih terdapat variabel lain yang berhubungan terhadap prestasi belajar sebesar $100 \%-14,2 \%$ $=85,8 \%$.

Hasil penelitian ini sejalan dengan yang di kemukakan oleh Ressa (2014) bahwa minat belajar adalah aspek psikologi seseorang yang menampakkan diri dalam beberapa gejala, seperti: gairah,motivasi, keinginan, perasaan suka untuk melakukan proses perubahan tingkah laku melalui berbagai kegiatan yang meliputi mencari pengetahuan dan pengalaman.

Minat diartikan sebagai suatu kondisi yang terjadi apabila seseorang melihat ciri-ciri atau arti sementara situasi yang dihubungkan dengan keinginan-keinginan atau kebutuhankebutuhannya sendiri.Dari beberapa pengertian di atas dapat dikatakan bahwa minat adalah kecenderungan tertarik pada sesuatu yang relatif tetap untuk lebih memperhatikan dan mengingat secara terus-menerus yang diikuti 
rasa senang.

Minat belajar adalah aspek psikologi seseorang yang menampakkan diri dalam beberapa gejala, seperti: gairah, keinginan, perasaan suka untuk melakukan proses perubahan tingkah laku melalui berbagai kegiatan yang meliputi mencari pengetahuan dan pengalaman.

Dari semua pengertian mengenai media pembelajaran di atas maka dapat di sintesakan bahwa yang dimaksud dengan minat belajar adalah kecendrungan dan kegairahan yang tinggi atau keinginan yang besar untuk belajar.

Menurut asumsi penelitian bahwa Mahasiswa denganminat belajar yang tinggi akan mendapatkan hasil yang baik sebaliknyamahasiswa dengan minat belajar rendah hasil belajarnya relatif lebih rendah.Dengan demikian minat belajar dapat dijadikan sebagai salah satu penentukeberhasilan proses belajar.

\section{Hubungan Media Pembelajaran Terhadap Motivasi Belajar di Kebidanan Widya Karsa Jayakarta Tahun 2015}

Media pembelajaran terhadap motivasi belajar dapat di ukur dengan menggunakan alat ukur kuesioner yaitu menjawab pertanyaan sebanyak 15 pertanyaan. Hasil keseluruhan kuesioner di akumulasikan dan di bagikan dengan jumlah responden sehingga di dapatkan nilai rata- rata motivasi belajar rendah sebanyak Berdasarkan tabulasi silang antara media pembelajaran dan motivasi belajar menunjukkan bahwa 18 mahasiswa yang media pembelajarannya tidak baik terdapat 14 responden( $77,8 \%)$ yang motivasinya rendah dan 4 responden $(22,2 \%)$ yang motivasinya tinggi. Sedangkan dari 12 mahasiswa yang media pembelajarannya baik terdapat 2 responden ( $16,7 \%$ ) memiliki motivasi rendah dan 10 responden $(83,3 \%)$ yang motivasi tinggi. Berdasarkan analisis uji Chi-Square pada tabel didapat nilai $r$ value $=0,002 \mathrm{Hal}$ ini menunjukkan bahwa $r<a(0,05)$, sehingga terdapat hubungan yang signifikan antara media pembelajaran dengan motivasi belajar. Dengan nilai OR 17.500 berarti responden yang menggunakan media pembelajaran tidak baik berpeluang 17 kali untuk memiliki motivasi belajar yang rendah di bandingkan yang tinggi.

Hal ini sesuai dengan penelitian yang dilakukan oleh Tria yang berjudul "Hubungan Media Pembelajaran Jobsheet dan Motivasi Belajar Terhadap Hasil Belajar Pada Mata Pelajaran Akuntansi Kelas XI IPS di SMA Pasundan 2 Bandung". Dari hasil penelitian didapat bahwa media pembelajaran jobsheet pada mata pelajaran akuntansi di kelas XI IPS SMA Pasundan 2 Bandung tergolong tinggi, motivasi belajar siswa tergolong sedang, dan hasil belajar siswa tergolong sedang. Dan hasil penelitian juga menunjukkan bahwa media pembelajaran jobsheet dan motivasi belajar berhubungan positif terhadap hasil belajar siswa.

Hal ini sesuai dengan teori yang dikemukakan oleh Hamalik (2008) mengemukakan bahwa pemakaian media pengajaran dalam proses belajar mengajar dapat membangkitkan keinginan dan minat yang baru, membangkitkan motivasi dan rangsangan kegiatan belajar, dan bahkan membawa pengaruh-pengaruh psikologis terhadap siswa.

Hal ini sesuai dengan penelitian M.Nur Awaludin (2010) yang berjudul "Penggunaan Media Pembelajaran untuk Meningkatkan Motivasi Siswa dalam Pembelajaran Fiqih di Madrasah Tsanawiyah Negeri Batu".Dalam penelitiannya tertulis sama dengan teori yang dikemukakan oleh Hamalik (2008) yaitu pemakaian media pengajaran dalam proses belajar mengajar dapat membangkitan keingintahuan dan minat baru bagi siswa, serta membangkitkan motivasi dan rangsangan kegiatan belajar mengajar dan bahkan membawa pengaruh psikologis terhadap siswa.

Menurut asumsi penelitian media pembelajaran bahwa semakin media pembelajaran memadai, semakin tinggi juga motivasi belajar siswa untuk belajar.Sebaliknya jika media pembelajaran tidak memadai, maka motivasi belajar siswa 
rendah.

\section{Hubungan Minat Belajar Terhadap Motivasi Belajar di Kebidanan Widya Karsa Jayakarta Tahun 2015}

Minat belajar terhadap motivasi belajar dapat di ukur dengan menggunakan alat ukur kuesioner yaitu menjawab pertanyaan sebanyak 15 pertanyaan.Hasil keseluruhan kuesioner di akumulasikan dan di bagikan dengan jumlah responden sehingga di dapatkan nilai rata- rata motivasi belajar rendah sebanyak.

Berdasarkan tabulasi silang antara minat belajar dan motivasi belajar menunjukkan bahwa 19 mahasiswi yang minatnya rendah terdapat 14 responden $(73,7 \%)$ yang motivasinya rendah dan 5 responden (26,3\%) yang motivasinya tinggi. Sedangkan dari 11 mahasiswi yang minatnya tinggi terdapat 2 responden $(18,2 \%)$ yang motivasinya rendah dan 9 responden $(81,8 \%)$ yang motivasinya tinggi. Berdasarkan analisis uji Chi-Square pada tabel didapat nilai $r$ value $=0,007$. Hal ini menunjukkan bahwa $r<\mathrm{a}(0,05)$, sehingga terdapat hubungan yang signifikan antara minat belajar dengan motivasi belajar. Dengan nilai OR 12.600 responden yang minat belajar yang rendah berpeluang 12 kali untuk memiliki motivasi yang rendah di bandingkan yang tinggi.

Hasil penelitian ini senada dengan penelitian Sardi (2013) Berdasarkan hasil penelitian minat belajar berpengaruh secara signifikan terhadap hasil belajar siswa kelas XI IPS MAN se-kota Pontianak.Dibuktikan dengan analisis regresi linear sederhana dimana nilai $t$ hitung sebesar $-2,859>$ nilai $t$ tabel sebesar -1,975. Hasil penelitian ini sejalan dengan pendapat Abied (2009) yang menyatakan bahwa jika minat belajar siswa dapat dibangkitkan, kemudian seluruh perhatiannya dapat dipusatkan kepada bidang studi yang dipelajarinya, keadaan kelas dapat menjadi tenang, dengan demikian proses belajar dapat berlangsung dengan baik dan siswa pun dapat mencapai tujuan belajar sebagaimana yang diharapkan.

Sedangkan Penelitian Agus Widiyatmo (2010) menyimpulkan ada hubungan antara minat dan motivasi belajar dengan prestasi belajar, besarnya hubungan kedua variabel bebas (minat belajar dan motivasi belajar) sebesar $14,2 \%$, dapat dijabarkan pengaruh masing-masing variabel bebas yaitu sumbangan efektif (SE\%) variabel minat belajar $=5 \%$, sedangkan sumbangan efektif $(\mathrm{SE} \%)$ variabel motivasi belajar $=3 \%$. Sehingga dapat dinyatakan bahwa masih terdapat variabel lain yang berhubungan terhadap prestasi belajar sebesar $100 \%-14,2 \%$ $=85,8 \%$.

Hasil penelitian ini sejalan dengan yang di kemukakan oleh Ressa bahwaminat belajar adalah aspek psikologi seseorang yang menampakkan diri dalam beberapa gejala, seperti: gairah,motivasi, keinginan, perasaan suka untuk melakukan proses perubahan tingkah laku melalui berbagai kegiatan yang meliputi mencari pengetahuan dan pengalaman.

Dalam penelitian ini, peneliti berasumsi bahwa Mahasiswa denganminat belajar yang tinggi akan mendapatkan hasil yang baik sebaliknyamahasiswa dengan minat belajar rendah hasil belajarnya relatif lebih rendah.Dengan demikian minat belajar dapat dijadikan sebagai salah satu penentukeberhasilan proses belajar.

\section{KESIMPULAN}

Berdasarkan hasil uraian penelitian yang telah peneliti lakukan dan dengan segala keterbatasan serta melihat pada tujuan penelitian mengetahui hubungan media pembelajaran dan minat belajar terhadap motivasi belajar di Kebidanan Widya Karsa Jayakarta tingkat III tahun 2015, dapat diambil kesimpulan.

Motivasi belajar di Kebidanan Widya Karsa Jayakarta tingkat III tahun 2015 sebanyak 14 orang (46,7\%). Penggunaan media pembelajaran yang Tinggi di Kebidanan Widya Karsa Jayakarta tingkat III tahun 2015 sebanyak 12 orang (40,0\%), sedangkan minat 
belajar di Kebidanan Widya Karsa Jayakarta tingkat III tahun 2015 sebanyak 11 orang $(36,7 \%)$.

Ada hubungan antara media pembelajaran terhadap motivasi belajar di Kebidanan Widya Karsa Jayakarta tingkat III tahun 2015 dengan nilai $r$ value $=0,002 \mathrm{Hal}$ ini menunjukkan bahwa $r<\mathrm{a}(0,05)$, sehingga terdapat hubungan yang signifikan antara media pembelajaran dengan motivasi belajar. Dengan nilai OR 17.500 berarti responden yang menggunakan media pembelajaran baik berpeluang 17 kali untuk mempunyai motivasi belajar.

Ada hubungan antara minat belajar terhadap motivasi belajar di Kebidanan Widya Karsa Jayakarta tingkat III tahun 2015 dengan nilai $r$ value $=0,007$. Hal ini menunjukkan bahwa $r<\mathrm{a}(0,05)$, sehingga terdapat hubungan yang signifikan antara minat belajar dengan motivasi belajar. Dengan nilai OR 12.600 responden yang minat belajar tinggi berpeluang 12 kali untuk mempunyai motivasi belajar.

\section{SARAN}

Diharapkan bagi institusi khususnya para dosen pengajar lebih meningkatkan motivasi belajar pada mahasiswa agar tetap terus semangat belajar dan mendapatkan hasil belajar yang baik.Serta meningkatkan penggunaan media pembelajaran dalam rangka meningkatkan motivasi belajar pada mahasiswi.Diharapkan peneliti selanjutnya dapat melakukan penelitian lebih lanjut dengan variabel- variabel yang belum di teliti.

\section{DAFTAR PUSTAKA}

Arianto. Minat Belajar.Jakarta. Rineka Cipta; 2008

Aziz, Atika Pendidikan.UNESCO.2012

Azhar, Arsyad. Media Pembelajaran. Jakarta: PT. Rajagrafindo Persada; 2011

Budiarto,Santo.Metodologi. Penelitian kuantitatif.EGC. Jakarta : 2002

Dimiyanti, Mudjiono.Belajar dan pembelajaran. Rineka cipta. Jakarta: 2010

Hamzah B. Uno.Teori Motivasi dan Pengukurannya: Analisis di Bidang Pendidikan. Jakarta: Bumi aksara; 2011

Hidayat, A, A. Riset Keperawatan dan Teknik Penulisan Ilmiah.Jakarta: Salemba Medika: 2011

Notoatmodjo,S. Pendidikan Kesehatan dan Ilmu Perilaku. Rineka Cipta : Jakarta. 2007

Oemar,Hamalik. Media Pendidikan. Bandung: Alumni; 2009.

Purwanto, M. Ngalim. Prinsip-prinsip dan Teknik Evaluasi Pengajaran, Bandung: PT Remaja Rosdakarya; 2009

Ridwan M. Metode dan Tehnik Penyusunan Tesis. Bandung:Alpabet; 2002

Sardiman.Interaksi dan Motivasi Belajar Mengajar. Jakarta: Raja Grafindo Persada; 2011

Sugiyono, Statistika untuk penelitian. Bandung : CV.Alfabeta; 2007

Woolfolk,Anita. Educational Active Psychology Learning Edition Edisi Kesepuluh Bagian Kedua, Yogyakarta: Pustaka Pelajar;2009 